http://dx.doi.org/10.18778/1508-1117.25.02

Magdalena Deptuła

\title{
TRADYCYJNE SZKOLY URBOMORFOLOGII A NOWE PODEJŚCIA DO ANALIZY MIEJSKICH FORM PRZESTRZENNYCH
}

\begin{abstract}
Zarys treści Artykuł jest próbą syntezy i usystematyzowania dotychczasowego dorobku w dziedzinie urbomorfologii. Opiera się na przeglądzie najważniejszych, tradycyjnych oraz najbardziej aktualnych tendencji w badaniach prowadzonych na tym polu. W pracy dokonano charakterystyki i porównania najważniejszych szkół europejskich zorientowanych na problematykę morfologii miast, wypracowanych na gruncie geografii i architektury. W tym celu prześledzono rozwój badań morfologicznych wywodzących się z trzech odmiennych tradycji: niemieckiej, brytyjskiej i włoskiej oraz zestawiono je z nowoczesnymi technikami analizy miejskich form przestrzennych, ze szczególnym uwzględnieniem space syntax (metody syntatyki przestrzeni). Artykuł ma na celu wskazać różnice $\mathrm{w}$ punkcie ciężkości badań morfologicznych prowadzonych w różnych obszarach badawczych, jednocześnie zaakcentować ich komplementarny potencjał poprzez prezentację różnych podejść teoretycznych i metodologicznych do struktur miejskich.
\end{abstract}

Słowa kluczowe Morfologia miast, geografia historyczna, architektura, filozofia, space syntax.

\section{Wprowadzenie}

Miasta od najdawniejszych czasów fascynowały uczonych i filozofów, stając się przedmiotem licznych traktatów, szkiców oraz innych prób uwiecznienia czasu i miejsca. Początkowo mocno uproszczone opisy i rysunki osad miejskich z czasem ewoluowały ukazując ich ogromne zróżnicowanie. Jednak dopiero rozwój kartograficznych metod prezentacji dostarczył wyczerpujących informacji przestrzennych, niezbędnych dla badań mających na celu rekonstrukcję procesu powstawania i ewolucji miast w czasie. Podstawą źródłową tych badań stały się „plany miast, które należą do najbardziej złożonych prezentacji kartograficznych 
- przedstawiają bowiem obszary o największej koncentracji różnego rodzaju obiektów i form działalności człowieka, będącymi rezultatem rozwoju cywilizacyjnego" (Ciołkosz-Styk 2013, s. 55). Wykorzystanie planu miasta jako źródła w badaniach geograficzno-historycznych zaowocowało wyłonieniem się w końcu XIX wieku nowej dyscypliny naukowej - urbomorfologii, zorientowanej na budowę wewnętrzną i zewnętrzną organizmów miejskich.

Obecnie teoria i praktyka badań z zakresu morfologii miast jest przedmiotem powszechnej debaty reprezentantów różnych dziedzin i dyscyplin nauki, w tym nie tylko geografii, historii i architektury, ale także nauk społecznych, filozofii, planowania przestrzennego $\mathrm{i}$ in. Wynika to $\mathrm{z}$ faktu, że nie jest możliwe przypisanie badań urbomorfologicznych tylko do jednej z nich. Mając na uwadze szeroki wachlarz sił kształtujących miasta oraz różnice w podejściu do formy przestrzennej u przedstawicieli różnych dyscyplin, najbardziej naturalne wydaje się zatem postrzeganie morfologii miast jako nauki interdyscyplinarnej. Odmienne sposoby przedstawiania $i$ analizy struktur miejskich $\mathrm{w}$ obrębie różnych środowisk naukowych zaowocowały wypracowaniem oryginalnych ujęć teoretycznych i analitycznych, dzięki którym możliwe jest dziś wyodrębnienie trzech głównych szkół morfologii miast w Europie, mianowicie niemieckiej, brytyjskiej i włoskiej. Zostały one omówione w ujęciu chronologicznym.

\section{Główne szkoły i kierunki badań z zakresu urbomorfologii w Europie}

Początki morfologii miast sięgają przełomu XIX i XX wieku, a związane są z działalnością badawczą wybitnych geografów niemieckich, głównie zaś O. Schlütera (1899a, 1899b), F. Ratzla (1903), H. Hassingera (1916), W. Geislera (1924) oraz R. Martiny'ego (1928), którzy analizę form miejskich opierali głównie na planie miasta (za: Oliveira 2013a). W tym okresie niemiecka geografia miast zajmowała się głównie morfologią osiedli miejskich rozumianą przede wszystkim w kontekście ich położenia, rozplanowania i fizjonomii (Koter, Kulesza 2008). Ten kierunek badań był kontynuowany m.in. przez H. Dörriesa (1925), który podobnie jak jego poprzednicy, podkreślał wagę opisu wyjaśniającego układów przestrzennych miast jako jednego z najważniejszych aspektów badawczych geografii osadnictwa miejskiego. Naturalnie z upływem lat niemiecka geografia miast znacznie się zróżnicowała wewnętrznie w zakresie problematyki badawczej i stosowanej terminologii. Z czasem $\mathrm{w}$ badaniach osadniczych wyłonił się nowy kierunek funkcjonalny, w krajach niemieckojęzycznych zainicjowany przez H. Bobka (1927). Jego rolę w badaniach morfologii miast, zwłaszcza w powiązaniu z analizą genezy przestrzeni kulturowych (Kulturraumgenese), w swoim raporcie z 1953 roku podkreślał również P. Schöller (za: Heineberg 2007).

Niemiecka szkoła geografii osadnictwa miejskiego odegrała dominującą rolę w kształtowaniu podejścia badawczego do form miejskich i rozwoju badań 
morfologicznych do lat 50. XX wieku. Po tym okresie nastąpił jednak wyraźny zastój w niemieckich badaniach z zakresu urbomorfologii. W epokę odrodzenia weszły one dopiero z początkiem lat 70 . XX wieku, jednak nie doprowadziło to już do wykształcenia znaczącej w skali europejskiej grupy badawczej czy ośrodka badań morfologicznych.

Równolegle z rozwojem szkoły niemieckiej w Wielkiej Brytanii i we Włoszech pojawiły się nowe ośrodki naukowo-badawcze zorientowane na badania z zakresu urbomorfologii. Ośrodki te rozwijały się niezależnie względem siebie, w odmiennych środowiskach naukowych, odpowiednio geograficznym oraz architektonicznym, wypracowując nowatorskie ujęcia teoretyczne i analityczne, które w latach powojennych zdominowały studia form miejskich w Europie.

Drugą ważną szkołą, jeśli nie najważniejszą dla współczesnych badań morfologicznych, była brytyjska szkoła morfologii miast powstała głównie w oparciu o działalność badawczą M.R.G. Conzena (1907-2000) - brytyjskiego geografa niemieckiego pochodzenia, który opierając się głównie na studiach O. Schlütera (1899a, 1899b) i W. Geislera (1924), odegrał kluczową rolę w kształtowaniu podwalin badań morfogenetycznych miast (Conzen 1960, 1962, 1968). Conzen opracował ramy pojęciowe dla morfologii miast, zaś jego osiągnięcia okazały się kluczowe dla zrozumienia złożoności krajobrazu miejskiego. Wprowadził m.in. jego trójpodział na: 1) plan miasta (obejmujący ulice, działki i budynki), 2) typy zabudowy oraz 3) formy użytkowania terenów miejskich, a także ustalił prawidła metodologiczne wykorzystania planu miasta jako podstawy źródłowej historycznej analizy morfologicznej (Conzen 1960). Jednak największe znaczenie dla rozwoju badań z zakresu urbomorfologii odegrały rozwinięte przez niego koncepcje wyjaśniające proces przeobrażeń struktur przestrzennych miast, spośród których wymienić należy koncepcję burgage cycle (cyklu przemian morfologicznych działki miejskiej) oraz koncepcję fringe belts (pasów/pierścieni obrzeży miejskich) (Koter, Kulesza 2007, 2008). Działalność naukowa Conzena, związana z Uniwersytetem w Birmingham, zaowocowała utworzeniem w 1974 roku Urban Morphology Research Group (UMRG), skupiającej wybitnych badaczy podtrzymujących badania morfologiczne w duchu tradycji conzenowskiej, spośród których wymienić należy przede wszystkim J.W.R. Whitehanda i jego studia zorientowane na rozwój koncepcji Conzena (Whitehand 1967, 1972, 1981, 1988, 1994). Z upływem lat w ramach UMRG wykrystalizowały się dwie sekcje badawcze odrębne pod względem problemowym. Pierwsza skupiła badaczy ukierunkowanych na kwestie planowania oraz rozwoju miast średniowiecznych i nowożytnych, zwłaszcza na analizę ich planów (np. Slater 1987; Baker, Slater 1992; Lilley 1999 , 2000). Druga sekcja kładzie szczególny nacisk na badania procesu przemian morfologicznych oraz roli podmiotów sprawczych odpowiedzialnych za przeobrażenia krajobrazu miejskiego w XX i XXI wieku (np. Whitehand 1992, 2003; Larkham 1996) (za: Heineberg 2007). Kierunki badawcze wypracowane w UMRG zyskały 
ogromną popularność $\mathrm{w}$ badaniach morfologicznych miast podejmowanych w wielu państwach europejskich (m.in. w Niemczech, Irlandii, Francji, Polsce, Hiszpanii czy Islandii), ale także w Stanach Zjednoczonych, Kanadzie, Australii, Turcji i Chinach. Ponadto od 1994 roku UMRG jest organizatorem International Seminar on Urban Form (ISUF), które stanowi międzynarodowe forum wymiany myśli w zakresie analizy form miejskich przedstawicieli różnych dyscyplin, głównie zaś archeologii, architektury, geografii, historii i planowania, przyczyniając się do popularyzacji badań morfologicznych w świecie.

Trzecią znaczącą szkołą morfologiczną była włoska szkoła morfologii miast, która rozwinęła się w oparciu o podejście typologiczne. Została założona w latach 50. XX wieku przez włoskiego architekta S. Muratoriego (1910-1973), niemniej jej początki sięgają pierwszych dekad XX wieku i badań m.in. G. Giovannoni i G. Pagano. Pierwszy z wymienionych, uważany za ojca włoskiej tradycji urbanistycznej, stworzył podwaliny nowocześnie pojmowanego projektowania miast. Postulował m.in. potrzebę przebudowy historycznych centrów oraz wymiany dawnej zabudowy na nową (Giovannoni 1930). Podobnie G. Pagano (1936), mimo iż poświęcił się studiom osadnictwa wiejskiego, dążył do zdefiniowania formy jako tymczasowej fazy w historycznym procesie przeobrażeń struktur przestrzennych.

Saverio Muratori natomiast rozwinął system filozoficzny wyjaśniający powstanie i przeobrażenia form miejskich w czasie, opierając analizę przestrzenną o typologię zabudowy (typomorfologię) (Muratori 1950, 1960, 1978). Według niego typy (zabudowy) stanowiły narzędzie do historycznej analizy struktur miejskich - każdy typ Muratori traktował jako rezultat historycznego rozwoju, który wykształca się z typu poprzedniego w efekcie wprowadzania w niego ewolucyjnych zmian. Zmiany te mogły być rezultatem dostosowania dawnej formy do nowego kontekstu cywilizacyjnego, jak również następować w konsekwencji wprowadzenia obcego typu i jego adaptacji do warunków lokalnych (za: Cataldi 2003).

Jedną z przewodnich cech szkoły muratoriańskiej było traktowanie historii jako sposobu na uzyskanie wrażenia ciągłości w praktyce architektonicznej. Podejście Muratoriego zakładało odrzucenie założeń ruchu modernistycznego. Korzeni architektury upatrywał on nie w nowoczesnych projektach modernistów, ale w ciągłości tradycji i stopniowej ewolucji zabudowy miasta od starożytności po współczesność. Poglądy Muratoriego były wyrazem dążenia do znalezienia kompromisu pomiędzy tendencjami do radykalnej przebudowy historycznych układów przestrzennych, zrywającymi łączność przeszłości-tradycji z nowoczesnością-innowacją, a traktowaniem miast jako muzeów. Tym samym jego celem stało się znalezienie praw ciągłości w procesie ewolucyjnych przemian tkanki miejskiej (za: Marzot 2002).

Muratori wyznaczył ramy unikalnej teorii uwzględniającej wszystkie elementy środowiska miejskiego, ich relacje oraz zależności, od pojedynczego budynku 
po całe zespoły zabudowy. Z czasem każdy z tych elementów z osobna stał się przedmiotem szczegółowych badań uczniów Muratoriego, m.in. G. Caniggi i G.L. Maffei (1978, 1981, 2001), M. Maretto (1980), A. Giannini (1980) czy R. Bollatiego (1980). Jednym z najbliższych był Caniggia, który potwierdził słuszność teorii Muratoriego oraz rozwinął potencjał zaproponowanej przez niego typologii zabudowy, dając jej podbudowę teoretyczną i metodologiczną. Metodę typologiczną zastosował on m.in. w studium Como (1963), włoskiego miasta o genezie rzymskiej, zaś wspólnie z Maffei opracował Compositione architettonica e tipologia edilizia (1979), sztandarowe dzieło włoskiej szkoły morfologii przetłumaczone na język hiszpański, francuski i angielski, w którym doprecyzowano metodologię typologii zabudowy. Przekładając teorię na praktykę, Caniggia przekonał środowisko naukowe do architektonicznej wizji Muratoriego. Ponadto, podobnie jak Muratori, postulował kontynuacyjny charakter planowania, z poszanowaniem historii i unikaniem rozwiązań doraźnych (Cataldi 2003).

Teorie Muratoriego i Caniggi są nadal aktualne - cieszą się dużym zainteresowaniem i w dalszym ciągu są rozwijane we włoskich ośrodkach badawczych m.in. w Genui, Florencji i w Rzymie (za: Cataldi, Maffei i Vaccaro 2002). Widoczne są również w kierunkach studiów z zakresu urbomorfologii podejmowanych przez badaczy form miejskich z Hiszpanii, Francji, Kanady, Irlandii, Szwecji i Portugali (za: Oliveira 2013a).

Z kolei w końcu XX wieku B. Hillier i J. Hanson z Bartlett School of Architecture na University College London (Hillier, Hanson 1984; Hillier 1996, 1999) opracowali nowy, innowacyjny system teorii i technik, znany powszechnie jako space syntax (syntaktyka przestrzeni), którego podstawę stanowi analiza ilościowa konfiguracji przestrzennych (Szmytkie 2014). W założeniach było to narzędzie mające pomóc architektom symulować prawdopodobne skutki społeczne swoich projektów. W praktyce stało się niezwykle popularną i interdyscyplinarną metodą analizy złożonych relacji między przestrzenią a szeregiem zjawisk społecznych, ekonomicznych i środowiskowych, które zrewolucjonizowało dotychczasową teorię i praktykę na polu urbanistyki, informatyki, badań archeologicznych, geograficznych miast, antropologicznych $\mathrm{i}$ in.

Metoda analizy w teorii Hilliera sprowadza się do zastosowania generatywnej syntaktyki przestrzeni opartej na tej teorii, w celu stworzenia opisu ładu przestrzennego. Zorientowana jest przede wszystkim na sieć uliczną, a oparta na dostępności przestrzeni jako głównym kryterium do analizy i projektowania. Zakłada, że przestrzenie dzielą się na składniki, które mogą być analizowane jako sieci wyborów i można je zobrazować w postaci opracowań graficznych (szeregu map i wykresów) w kontekście ich zdolności przyłączeniowych (Szmytkie 2014). Metoda space syntax zdobyła szerokie uznanie jako narzędzie interdyscyplinarne. Jest obecnie powszechnie stosowana w różnych obszarach badawczych, m.in. do analizy sieci ulicznej (O'Sullivan 2000; Controy-Dalton, Dalton 2007), 
wyznaczania obszarów centralnych (Hillier 1999), typologii budynków (Hillier i in. 1987), jak również w badaniach historycznych (Griffiths 2012) i społecznych (Dara-Abrams 2009). Umożliwia m.in. wyjaśnienie hierarchii elementów układu w odniesieniu do konkretnego obszaru lub budynku oraz obrazuje, w jaki sposób dany wzorzec przestrzenny zawiera w sobie treść i informację społeczną. Interesujące są również analizy spójności organizmów miejskich powstałych z połączenia kilku miast przy użyciu space syntax (Cho 2011). Badania tego typu podjęte zostały również w ośrodku wrocławskim w odniesieniu do analizy spójności tzw. miast zlepieńców (Szmytkie 2009). Space syntax wywarł znaczący wpływ na badania morfologiczne podejmowane m.in. w Turcji, Portugalii, Korei Południowej i Szwecji.

\section{Nowe podejścia do analizy form przestrzennych}

Postęp w dziedzinie oprogramowania, jaki nastąpił w czasie ostatniej dekady XXI wieku, dostarczył nowych możliwości analiz, tak jakościowych, jak i ilościowych przestrzeni miejskiej. Umożliwił wizualizację oraz analizę przestrzenną i społeczno-ekonomiczną różnych atrybutów form miejskich (Conzen 2010; Stanilov 2010). Przyczynił się do udoskonalenia istniejących metod i technik, jak chociażby space syntax, ale również spowodował pojawienie się nowych, m.in. mixed-use index (MXI) (Hoek 2009) i spacematrix (Berghauster Pont, Haupt 2010), które zwiększyły możliwości analityczne przestrzeni miejskiej poprzez umożliwienie pomiaru stopnia zróżnicowania użytkowania ziemi i gęstości zabudowy. W ostatnich latach, dzięki rozwojowi narzędzi komputerowych, kolejni badacze dostarczają nowych propozycji metod analizy morfologicznej struktur miejskich (np. Griffiths i in. 2009; Osmond 2010; Gil i in. 2012; Ståhle 2012; Oliveira 2013b). Szczególnej uwagi na tym polu wymagają zwłaszcza osiągnięcia szwedzkiego ośrodka badawczego, gdzie zaproponowano rozwinięcie teorii space syntax w postaci place syntax, łączącej dostępność systemu ulicznego z informacjami o gęstości zabudowy oraz układzie bloków urbanistycznych i działek (Ståhle 2012). Duże zainteresowanie wzbudziła również zaproponowana przez V. Oliveira (2013b) z Uniwersytetu w Porto metoda pomiaru form miejskich określana mianem morpo, uwzględniająca podstawowe elementy morfologii miasta, mianowicie ulice, działki i zabudowę. Metoda ta, opracowana przede wszystkim z myślą o praktyce planistycznej, umożliwia ilościową ocenę morfologicznej bazy (morphological base) terenów miejskich ze wskazaniem ich mocnych oraz słabych stron.

Dynamiczny rozwój nowych technik i metod analiz przestrzennych oraz równoległe zastosowanie Systemu Informacji Geograficznej (GIS) jako narzędzia umożliwiającego połączenie znacznej liczby danych źródłowych o charakterze powierzchniowym, społecznym i gospodarczym, stwarza wiele możliwości 
w badaniach nad miastami. Znaczenie GIS jako ważnego narzędzia integrującego oryginalne metody analizy przestrzennej podkreślali w swych pracach m.in. B. Jiang $\mathrm{i}$ in. (2000), B. Jiang i Claramunt (2002), L. Marcus (2010), J. Gil i in. (2012). Natomiast P. Pinho i V. Oliveira (2009a, 2009b) oraz M. Serra i P. Pinho (2011) stali się pionierami opartej na GIS metody historycznej analizy miasta z zastosowaniem space syntax. Zaproponowane przez nich podejście obejmuje szczegółową rekonstrukcję kartograficzną struktury przestrzennej dla każdego okresu historycznego w ujęciu retrospektywnym.

Niestety, większość nowoczesnych metod, technik i narzędzi analiz osiedli miejskich nie uwzględnia łącznie wszystkich aspektów przestrzennych. Mając na uwadze niedostatki dotychczasowych rozwiązań, Y. Ye z Uniwersytetu w Hong Kongu i A. van Nes z Uniwersytetu Technologii w Niderlandach zaproponowali zintegrowane podejście w postaci metody modelowania przestrzeni, która wykorzystując GIS łączy analizę trzech elementów składowych krajobrazu miejskiego rozpoznanych przez M.R.G. Conzena (Ye, Nes 2014). Ich celem było opracowanie systemu klasyfikacji przestrzennej dla różnych typów obszarów miejskich i wykazanie, jaką rolę odgrywają one na płaszczyźnie socjoekonomicznej. W zaproponowanej metodzie zastosowano łącznie space syntax, spacematrix i MXI w celu oszacowania stopnia integracji sieci ulicznej, gęstości zabudowy i sposobu użytkowania ziemi, a następnie wykorzystano ją do porównania parametrów przestrzennych trzech nowych miast i jednego miasta historycznego w Niderlandach. Wykazano, że zaproponowane, zintegrowane podejście do miejskiej formy przestrzennej stanowi dobre narzędzie diagnostyczne umożliwiające wskazanie sposobów udoskonalenia warstwy socjoekonomicznej w przestrzeni miejskiej. Ponadto metoda ta ułatwiła wskazanie współzależności pomiędzy stopniem integracji sieci ulicznej a gęstością zabudowy oraz sposobem użytkowania ziemi w procesie przeobrażeń struktur miejskich.

\section{Dyskusja i wnioski}

Generalnie badania z zakresu morfologii miast można podzielić na trzy główne kategorie w zależności od dziedziny i dyscypliny nauki, na gruncie której są podejmowane, mianowicie geografii, architektury i nauk ścisłych.

Na polu geografii szkoła brytyjska (conzenowska) odgrywa rolę wiodącą. Podobnie w dziedzinie architektury przoduje szkoła włoska. Ośrodki te prezentują zupełnie odmienne podejście do badań urbomorfologicznych, kładąc nacisk na różne aspekty przestrzenne - odpowiednio na badania krajobrazu miejskiego w oparciu o analizę planu miasta (szkoła brytyjska) oraz analizę typologii zabudowy wewnętrznych struktur osiedli (szkoła włoska). W brytyjskiej szkole morfologicznej dominuje podejście geograficzne, nie mające nic wspólnego ze szczegółowymi badaniami typomorfologicznymi podejmowanymi w szkole 
włoskiej, mającymi z kolei ścisły związek z praktyką planistyczną i architektoniczną. Zupełnie odmienne podejście do morfologii miasta prezentuje ujęcie syntaktyczne, które umożliwia analizę form przestrzennych opartą na metodach matematycznych. Integrując różne metody i techniki analityczne space syntax stanowi niezwykle interesujące narzędzie interdyscyplinarne.

Warto zauważyć, że mimo różnic na polu teorii oraz praktyki analitycznej form miejskich, poszczególne ujęcia badawcze wyrosłe w różnych obszarach nauki mają elementy spójne. Przede wszystkim opierają się na przekonaniu, że zrozumienie środowiska miejskiego jest możliwe poprzez analizę trzech wymiarów, mianowicie formy, czasu i skali (Griffiths 2012). Warto w tym miejscu podkreślić przede wszystkim znaczenie kontekstu historycznego, jako ważnego aspektu wyznaczającego ramy analityczne dla badań krajobrazu miejskiego, który jest widoczny w trzech omówionych podejściach do formy przestrzennej. Tradycyjne ujęcie morfologiczne szkoły brytyjskiej ukierunkowane jest na wyjaśnienie procesu powstawania i ewolucji krajobrazu miejskiego w czasie. Włoska szkoła dostarcza teoretyczną podstawę dla projektowania i planowania miast z poszanowaniem historycznej tradycji zabudowy. Również space syntax posiada potencjał do badań historycznych miast, mimo iż powszechnie uznawany jest głównie za narzędzie analityczne architektów, urbanistów i planistów.

Generalnie można wskazać trzy główne nurty badań historycznych miast opierających się na space syntax. W pierwszej kolejności są to badania zorientowane na analizę sposobu, w jaki element społeczny organizuje przestrzeń i jest przez nią organizowany w czasie (np. Thaler 2005; Griffiths 2009; Letesson 2010). Badania te mają na celu wyjaśnienie socjoekonomicznych oraz kulturowych aspektów tzw. kultury miasta.

Drugi nurt badań syntaktycznych miast uwzględniających aspekt historyczny stanowią studia mające na celu eksplorację związku między procesem przeobrażeń morfologii osiedli w czasie a aktywnością społeczną (np. Karimi 2000; Medeiros i in. 2003; Medeiros, Holanda 2007; Griffiths i in. 2010). Ujęcie to wprowadza kontekst społeczny konfiguracji przestrzennej osadnictwa i form architektonicznych w celu pełnego zrozumienia współczesnego środowiska zabudowanego.

W trzecim wyodrębniającym się kierunku badań historia traktowana jest jako syntaktyczny proces rozwoju (syntactical growth process) osiedli miejskich i ewolucji typologii zabudowy (np. Kigawa, Furuyama 2005; Hanna 2009; Shpuza 2009). Znaczna część opracowań zorientowanych na tę problematykę wykorzystuje kartografię historyczną jako bazę dla modelu procesu rozwoju miast. Niemniej, jak w większości studiów z zakresu space syntax, tak i w tym przypadku punkt ciężkości leży w zrozumieniu i wyjaśnieniu społecznej logiki tego procesu. Prace ukierunkowane są głównie na modelowanie konfiguracyjne samego obiektu badań, mają przede wszystkim charakter ilościowy, zaś kontekst historyczny sprowadza się do porównania następujących po sobie faz w przeobrażeniach 
form miejskich. Powyższy przegląd dowodzi szerokich możliwości zastosowania metody space syntax $\mathrm{w}$ badaniach historycznych miast zorientowanych przede wszystkim na relacje pomiędzy formą przestrzenną miast a społecznym życiem miasta.

Wszystkie omówione szkoły morfologii miast w Europie dążą do odnalezienia prawidłowości w rozwoju osiedli miejskich oraz ich opisu za pomocą konkretnych schematów i wzorów. Chociaż wykształciły się w odmiennym kontekście społeczno-kulturowym i są nastawione na różne aspekty przestrzenne, to razem mogą stanowić ważne narzędzie dla studiów form miejskich. Ich powiązanie, tak w zakresie teorii, jak i metodologii badań może wykazać, że są względem siebie komplementarne i umożliwić pełniejsze ujęcie analityczne struktur miejskich. Ich współdziałanie może również pozytywnie wpłynąć na przyszłe analizy morfologiczne miast i wydaje się elementem pożądanym.

\section{Podsumowanie}

Formy przestrzenne miast stanowią przedmiot zainteresowań reprezentantów wielu dziedzin i dyscyplin naukowych, którzy kładąc nacisk na odmienne aspekty przestrzeni miejskiej, a także stosując zróżnicowane metody i techniki badawcze, dowodzą złożoności krajobrazu miejskiego oraz szerokich możliwości jego analizy. Jednocześnie te odmienne podejścia do struktur miejskich w obrębie różnych środowisk naukowych wyznaczają autonomiczne pola badawcze w ramach jednej dyscypliny, jaką jest morfologia miast.

W ostatnich latach badania urbomorfologiczne cieszą się wzrastającym zainteresowaniem, zwłaszcza na polu projektowania przestrzeni miejskiej. Spowodowane jest to m.in. dwoma zjawiskami, które są aktualnie w centrum debaty nad przyszłością miast, mianowicie: 1) gwałtownym wzrostem liczby ludności miejskiej związanym z procesem globalizacji, 2) przy jednoczesnym dążeniu do zrównoważonego rozwoju przestrzeni miast z poszanowaniem reliktów przeszłości. Mając na uwadze świadomość problemów związanych z rosnącą gęstością zaludnienia, jednocześnie zaś możliwość retrospekcji procesu historycznego rozwoju miast oraz analizy agregatowego charakteru form miejskich, jak i mechanizmów ich transformacji oraz adaptacji w czasie, urbomorfologia odgrywa rolę pomostu między historią a współczesnym projektowaniem miast, dostarczając wachlarz ważnych i praktycznych narzędzi analitycznych i prognostycznych. Jak pisze M. Maretto „miasto (...) jest przejawem złożonych nawarstwień społecznych, gospodarczych i kulturowych (...), zaś morfologia miast jest potencjalnym instrumentem łączącym zróżnicowane technologie oraz kulturowe, społeczne i obywatelskie potrzeby" (Maretto 2013, s. 93). Warto zatem podkreślić, że badania z zakresu morfologii i fizjonomii jednostek osadniczych mają ogromny potencjał, tym większy jeśli rozpatrywany w kontekście możliwości łącznego 
wykorzystania technik i narzędzi analitycznych opracowanych w różnych obszarach nauki. Jako niezwykle ważny interdyscyplinarny nurt badawczy analizy morfologiczne mogą stanowić punkt wyjścia dla działalności m.in. projektantów, architektów, planistów i urbanistów, inspirując do tworzenia kreatywnych rozwiązań oraz praktycznych pomysłów zarządzania i projektowania środowisk zabudowanych.

\section{LITERATURA}

Baker N.T., Slater T.R., 1992, Morphological regions in British medieval towns, [in:] Whitehand J.W.R., Larkham P.J. (eds), Urban landscapes: international perspectives, Routledge, London, s. 43-68.

Berghauster Pont M., Haupt P., 2010, Spacematrix: space, density and urban form, Netherlands Architecture Institute, Amsterdam.

Bobek H., 1927, Grundfragen der Stadtgeographie, „Geographischer Anzeiger”, 28(7), s. 213-24.

Bollati R., 1980, Metodo di lettura delle strutture urbane, attraverso le fasi evolutive, Istituto Universitario Statale di Architettura, Reggio Calabria.

Caniggia G., 1963, Lettura di una città: Como, Centro Studi di Storia Urbanistica, Roma.

Caniggia G., Maffei G.L., 1978, Lettura dell'edilizia di base, Marsilio Editori, Padova.

Caniggia G., Maffei G.L., 1979, Compositione architettonica e tipologia edilizia. I Lettura dell'edilizia di base, Marsilio, Venezia.

Caniggia G., Maffei G.L., 1981, Strutture dello spazioantropico, Alinea, Firenze.

Caniggia G., Maffei G.L., 2001, Architectural composition and building typology: interpreting basic building, Alinea, Firenze.

Cataldi G., 2003, From Muratori to Caniggia: the origins and development of the Italian school of design typology, „Urban Morphology” 7(1), s. 19-34.

Cataldi G., Maffei G.L., Vaccaro P., 2002, Saverio Muratori and the Italian school of planning typology, „Urban Morphology”, 6(1), s. 3-14.

Cho H., 2011, Future Korean Urban Transformation as the result of Integration of Urban Administrative Districts, The Asian Conference on Asian Studies 2011, Conference Proceedings, International Academic Forum, s. 117-131.

Ciołkosz-Styk A., 2013, Zastosowanie metody cyfrowego przetwarzania obrazów do wyznaczania gęstości graficznej opracowań kartograficznych na przykładzie planów miast, „Archiwum Fotogrametrii, Kartografii i Teledetekcji”, 25, s. 55-66.

Controy-Dalton R., Dalton N., 2007, Applying Depth Decay Functions to Space Syntax Network Graphs, (Proceedings) Sixth International Space Syntax Symposium.

Conzen M.P., 2010, The elusive common denominator in understanding urban form, „Urban Morphology", 14, s. 55-58.

Conzen M.R.G., 1960, Alnwick, Northumberland; a Study in Town-Plan Analysis, Publication 27, Institute of British Geographers, London.

Conzen M.R.G., 1962, The plan analysis of an English city centre, [in:] Norborg K. (eds.), Proceedings of the IGU Symposium in Urban Geography, Gleerup, Lund, s. 383-414.

Conzen M.R.G., 1968, The use of towns plans in the study of urban history, [in:] Doys H.J. (eds.), The study of urban history, London, s. 113-130. 
Dara-Abrams D., 2009, Extracting Cognitively Relevant Measures from Environmental Models, [in:] Koch D., Steen J. (eds.), Proceedings of the $7^{\text {th }}$ International Space Syntax Symposium, Stockholm.

Dörries H., 1925, Die Städte im oberen Leinetal, Göttingen, Northeim und Einbeck. Ein Beitrag zur Landeskunde Niedersachsens und zur Methodik der Stadtgeographie, Vandenhoeck \& Ruprecht, Göttingen.

Geisler W., 1924, Die deutsche Stadt. Ein Beitrag zur Morphologie der Kulturlandschaft, „Forschungen zur deutschen Landes und Volkskunde”,22(5), Engelhorn, Stuttgart.

Giannini A., 1980, L'individuo territoriale, Istituto di Progettazione Architettonica, Genova.

Gil J., Beirão J.N., Montenegro N., Duarte J., 2012, On the discovery of urban typologies: data mining the many dimensions of urban form, „Urban Morphology”, 16, s. 27-40.

Giovannoni G., 1930, Vecchie citta ed edilizia nuova, Unione Tipografico-Editrice Torinese, Torino.

Griffiths S., 2009, Persistence and Change in the Spatio-temporal Description of Sheffield Parish 1770-1910, [in:] Koch D., Marcus L., Steen J. (eds.), Proceedings of the $7^{\text {th }}$ International Space Syntax Symposium, Stockholm, KTH Royal Institute of Technology, 37, s. 1-15.

Griffiths S., 2012, The use of Space Syntax in Historical Research: current practice and future possibilities, [in:] Greene M., Reyes J., Castro A. (eds.), Proceedings: Eight International Space Syntax Symposium, Santiago de Chile.

Griffiths S., Jones C., Vaughan L., Haklay M., 2010, The persistence of suburban centres in Greater London: combining Conzenian and space syntax approaches, „Urban Morphology", 14(2), s. 85-99.

Hanna S., 2009, Spectral comparison of large urban graphs, [in:] Koch D., Marcus L., Steen J. (eds.), Proceedings of the $7^{\text {th }}$ International Space Syntax Symposium, Stockholm, KTH Royal Institute of Technology, 39, s. 1-11.

Hassinger H., 1916, Kulturhistorischer Atlas der K.K. Reichshaupt- und Residenzstadt Wien, und Verzeichnis der erhaltenswerten historischen Kunst- und Naturdenkmale des Wiener Stadtbildes, „Österreichische Kunsttopographie”, 15, Schroll, Wien.

Heineberg H., 2007, German geographical urban morphology in an international and interdisciplinary framework, „Urban Morphology”, 11 (1), s. 5-24.

Hillier B., 1996, Space is the machine: a configurational theory of architecture, Cambridge University Press, Cambridge.

Hillier B., 1999, Centrality as a process: accounting for attraction inequalities in deformed grids, „Urban Design International”, 4(3-4), s. 107-127.

Hillier B., Hanson J., 1984, The social logic of space, Cambridge University Press, Cambridge.

Hillier B., Hanson J., Graham H., 1987, Ideas are in things: an application of the space syntax method to discovering house genotypes, ,Environment and Planning B”, 14, s. 363-385.

Hoek J. van den, 2009, The Mixed-use Index as planning tool for new towns in the $21^{\text {st }}$ Century, [in:] Stolk E., Brömmelstroet M.T. (eds.), New towns for the $21^{\text {st }}$ century: the planned vs the unplanned city, SUN Architecture, Amsterdam, s. 198-207.

Jiang B., Claramunt C., Klarqvist B., 2000, Integration of space syntax into GIS for modeling urban space, „International Journal of Applied Earth Observation and Geoinformation", 2, s. 161-171. 
Jiang B., Claramunt C., 2002, Integration of Space Syntax into GIS: New Perspectives for Urban Morphology, „Transactions in GIS”, 6(3), s. 295.

Karimi K., 2000, Urban conservation and spatial transformation: preserving the fragments or maintaining the 'spatial spirit', „Urban Design International”, 5, s. 221-231.

Kigawa T., Furuyama M., 2005, Kyoto: A morphological cycle between a city of rituals and a city of games, Proceedings $5^{\text {th }}$ International Space Syntax Symposium, Delft, TU Delft, Faculty of Architecture, s. 697-713.

Koter M., Kulesza M., 2007, Morfologia miast - stan i tendencje rozwoju, [w:] Jażdżewska I. (red.), Polska geografia osadnictwa. Dotychczasowy dorobek. Program badań, XX Konwersatorium Wiedzy o Mieście, Katedra Geografii Miast i Turyzmu UŁ, Łódź, s. 303-314.

Koter M., Kulesza M., 2008, Zastosowanie metod conzenowskich w polskich badaniach morfologii miast, [w:] Kulesza M. (red.), Czas i przestrzeń w naukach geograficznych. Wybrane problemy geografii historycznej, UŁ, Łódź, s. 257-272.

Larkham P.J., 1996, Conservation and the city, Routledge, London.

Letesson, Q., 2010, Du phénotype au génotype: Analyse de la syntaxe spatiale en architecture minoenne, Published PhD thesis, University of Louvain Press.

Lilley K.D., 1999, Urban landscapes and the cultural politics of territorial control in Anglo-Norman England, „Landscapes Research”, 24, s. 5-23.

Lilley K.D., 2000, Mapping the medieval city: plan analysis and urban history, „Urban History", 27, s. 5-30.

Marcus L., 2010, Spatial capital and how to measure it: a proposal for an extension of space syntax into a more general urban morphology, ,Journal of Space Syntax”, 1, s. $30-40$.

Maretto M., 1980, Realtà naturale e realtà della costruita, Uniedit, Firenze.

Maretto M., 2013, Severio Muratori: towards a morphological school of urban design, „Urban Morphology”, 17 (2), s. 93-106.

Martiny R., 1928, Die Grundrißgestaltung der deutsche Siedlungen, Petermanns Mitteilungen, „Ergänzungsheft”, 197, Perthes, Gotha.

Marzot N., 2002, The study of urban form in Italy, „Urban Morphology”, 6(2), s. 59-73.

Medeiros V., Holanda F., Trigueiro E., 2003, From Compact Colonial Villages to Sparse Metropolis, Proceedings, $4^{\text {th }}$ International Space Syntax Symposium, UCL, London, s. 12.1-12.16.

Medeiros V., Holanda F., 2007, Structure and size: Brazilian cities in an urban configurational world scenario, Proceedings $6^{\text {th }}$ International Space Syntax Symposium Istanbul, Istanbul Technical University Faculty of Architecture, 029.01-12.

Muratori S., 1950, I caratteri degli edifici nello studio dell'architettura, Instituto Universitario di Architettura, Venezia.

Muratori S., 1960, Studi per una operante storia urbana di Venezia, Instituto poligrafico dello Stato, Libreria dello Stato.

Muratori S., 1978, Metodologia del sistema realtà-autocoscienza, Centro Studi di Storia Urbanistica, Roma.

O'Sullivan D., 2000, Graph-based cellular automation models of urban spatial processes, University College London, University of London, London. 
Oliveira V., 2013a, The study of urban form: reflections on national reviews, „Urban Morphology", 17 (2), s. 85-92.

Oliveira V., 2013b, Morpho: a methodology for assessing urban form, „Urban Morphology", 14, s. 5-20.

Osmond P., 2010, The urban structural unit: towards a descriptive framework to support urban analysis and planning, „Urban Morphology”, 14, s. 5-20.

Pagano G., Daniel G., 1936, Architettura rurale italiana, Ulrico Hoepli Editore, Milano.

Pinho P., Oliveira V., 2009a, Combining different methodological approaches to analyze the Oporto Metropolitan Area, [in:] Koch D., Marcus L., Steen J. (eds.), Proceedings of the $7^{\text {th }}$ International Space Syntax Symposium, Stockholm, KTH Royal Institute of Technology, 88, s. 1-13.

Pinho P., Oliveira V., 2009b, Cartographic analysis in urban morphology, „Environment and Planning B: Planning and Design”, 36, s. 107-127.

Ratzel F., 1903, Die geographische Lage der großen Städte Großstadt, „Jahrbuch der Gehe-Stiftung", 9, v. Zahn \& Jaensch, Dresden.

Schlüter O., 1899a, Bemerkungen zur Siedlungsgeographie, „Geographische Zeitschrift”, 5 , s. $65-84$.

Schlüter O., 1899b, Über den Grundriß der Städte, ,Zeitschrift der Gesellschaft für Erdkunde zu Berlin", 34, s. 446-462.

Schöller P., 1953, Aufgaben und Probleme der Stadtgeographie, „Erdkunde”, 7 (3), s. $161-184$.

Serra M., Pinho P., 2011, Dynamics of periurban spatial structures: investigating differentiated patterns of change on Oporto's urban fringe, „Environment and Planning B: Planning and Design", 38, s. 359-382.

Shpuza E., 2009, Evolution of Street Networks in Adriatic and Ionian Coastal Cities 1769-2007, [in:] Koch D., Marcus L., Steen J. (eds.), Proceedings of the $7^{\text {th }}$ International Space Syntax Symposium, Stockholm, KTH Royal Institute of Technology, 101, s. $1-15$.

Slater T.R., 1987, Ideal and reality in English episcopal medieval town planning, Transactions of the Institute of British Geographers, New Series 12, s. 191-203.

Stanilov K., 2010, Brigding the gap between urban morphology and urban modeling, „Urban Morphology”, 14, s. 123-124.

Ståhle A., 2012, Place Syntax Tool (PST), [in:] Hull A., Silva C., Bertolini L. (eds.), Accessibility Instruments for Planning Practice, COST Office, s. 173-178.

Szmytkie R., 2009, Miasta-zlepieńce na Ślasku Dolnym i Opolskim, Rozprawy Naukowe Instytutu Geografii i Rozwoju Regionalnego Uniwersytetu Wrocławskiego, 6, Uniwersytet Wrocławski, Wrocław.

Szmytkie R., 2014, Metody analizy morfologii i fizjonomii jednostek osadniczych, Rozprawy Naukowe Instytutu Geografii i Rozwoju Regionalnego, 35, Uniwersytet Wrocławski, Wrocław.

Thaler U., 2005, Narrative and Syntax: new perspectives on the Late Bronze Age palace of Pylos, Greece, Proceedings $5^{\text {th }}$ International Space Syntax Symposium, Delft, TU Delft, Faculty of Architecture, s. 324-339.

Whitehand J.W.R., 1967, Fringe belts: a neglected aspect of urban geography, „Transactions", 41, Institute of British Geographers, s. 223-233. 
Whitehand J.W.R., 1972, Building cycles and the spatial pattern of urban growth, „Transactions", 56, Institute of British Geographers, s. 39-55.

Whitehand J.W.R., 1981, Conzenian ideas: extention and development, [in:] Whitehand J.W.R. (eds.), The urban landscape: historical development and management, Papers by M.R.G. Conzen, Institute of British Geographers. Special Publication, 13, Academic Press, London.

Whitehand, J.W.R., 1988, Urban fringe belts: development of an idea, „Planning Perspectives", 3, s. 47-58.

Whitehand J.W.R., 1992, The making of the Urban landscape, Institute of British Geographers, Special Publication, 26, Blackwell, Oxford.

Whitehand J.W.R., 1994, Development cycles and urban landscapes, „Geography”, 79, s. $3-17$.

Whitehand J.W.R., 2003, Suburban residential building form: a historio-geographical approach, [in:] Bischoff C.A., Krajewski C. (eds.), Beiträge zur geographischen Stadt- und Regionalforschung, 46, Institut für Geographie, Münster, s. 165-174.

Ye Y., Nes van A., 2014, Quantitative tools in urban morphology: combining space syntax, spacematrix and mixed-use index in GIS framework, „Urban Morphology”, 18 (2), s. $98-118$.

\section{TRADITIONAL SCHOOLS OF URBAN MORPHOLOGY AND THE NEW APPROACHES TO THE ANALYSIS OF URBAN FORMS}

Abstract This article is based on review of the most important, traditional as well as the most recent, trends in studies of urban morphology. It provides a comparative synthesis of the major European schools of urban morphology, developed in the field of geography and architecture. For this purpose, it traces the development of morphological studies derived from three distinct traditions: German, British and Italian, and compare them with modern techniques of analysis of urban spatial forms, with particular emphasis on space syntax. Through the presentation of different theoretical and methodological approaches to urban structures the article aims to demonstrate the differences in the focus of morphological studies conducted in different areas of research. At the same time it accentuate their complementary potential.

Keywords Urban morphology, historical geography, architecture, philosophy, space syntax.

Dr Magdalena Deptuła Katedra Geografii Politycznej i Studiów Regionalnych Wydział Nauk Geograficznych Uniwersytet Łódzki 